\title{
Kinsloe Focus Artifact Assemblages and Nadaco Caddo
}

Timothy K. Perttula

Heritage Research Center, Stephen F. Austin State University

Follow this and additional works at: https://scholarworks.sfasu.edu/ita

Part of the American Material Culture Commons, Archaeological Anthropology Commons, Environmental Studies Commons, Other American Studies Commons, Other Arts and Humanities Commons, Other History of Art, Architecture, and Archaeology Commons, and the United States History Commons

Tell us how this article helped you.

This Article is brought to you for free and open access by the Center for Regional Heritage Research at SFA ScholarWorks. It has been accepted for inclusion in Index of Texas Archaeology: Open Access Gray Literature from the Lone Star State by an authorized editor of SFA ScholarWorks. For more information, please contact cdsscholarworks@sfasu.edu. 


\section{Kinsloe Focus Artifact Assemblages and Nadaco Caddo}

Creative Commons License

(c) $($ i) (9)

This work is licensed under a Creative Commons Attribution-NonCommercial 4.0 International License 


\section{KINSLOE FOCUS ARTIFACT ASSEMBLAGES AND NADACO CADDO}

\section{Timothy K. Perttula}

The Kinsloe focus (now phase) was defined by Jones (1968) on the basis of seven sites in Gregg, Harrison, and Rusk counties in East Texas, in the middle reaches of the Sabine River basin (see Figure 1 in Perttula and Middlebrook, this volume). These sites are Ware Acres (41GG31), Kinsloe (41GG3), Susie Slade (41HS13), Brown 1 (41HS261), C. D. Marsh (41HS269), Millsey Williamson (41RK3), and Cherokee Lake (41RK132). As currently understood, these historic Caddo sites were most likely occupied by Nadaco Caddo people between ca. A.D. 1680-1800.

For our purposes here, my interest is in compiling in one place the characteristic material culture items found in the known Kinsloe phase sites as a whole, even though it is recognized that the seven sites probably were not all contemporaneously occupied and some of them may date as early as the late $17^{\text {th }}$ century and others may date as late as the early $19^{\text {th }}$ century. This compilation will be useful in any basic comparisons that may be made between the archaeology and material culture of the Nadaco Caddo and other historic Caddo groups living in East Texas, particularly in the diverse composition of ceramic vessel assemblages and the abundance and range of European trade goods obtained by the various Caddo groups from the French, Spanish, and English traders.

However, without a completely new and comprehensive reanalysis of the Kinsloe phase material culture, presuming that these assemblages can even be successfully reassembled and made available for study, we must perforce rely on the information presented (sometimes sketchily) in Jones (1968), the basic source on the Kinsloe phase. The Buddy Jones collection is now at the Gregg County Museum in Longview, Texas, and a documentation effort reported by Perttula (2006) was not successful in locating much of the archaeological material from the seven Kinsloe phase sites discussed by Jones.

The compilation of Kinsloe phase material culture from Jones (1968) is provided in Table 1. Where numbers are provided among the ceramic vessels, the most common vessel types are a grog-tempered plain ware (Henderson Plain), Simms Engraved, including a new variety of Simms Engraved (var. Darco) that replaces the type Darco Engraved defined by Jones (1968), Natchitoches Engraved, and a punctated-incised utility ware jar that closely resembles Emory Punctated-Incised. The presence of Patton Engraved in these burial collections points to contacts between the Nadaco and Hasinai Caddo groups in the Neches-Angelina River basin, while Taylor Engraved and Hudson Engraved vessels suggest interaction between the Nadaco and Caddo groups living in the Big Cypress and Red River basins to the north. 
Table 1. Kinlsoe Phase Material Culture Assemblage.

\begin{tabular}{|c|c|c|c|}
\hline Vessels & No. & Trade Goods & No. \\
\hline Henderson Plain & 19 & Iron awls & $\mathbf{P}$ \\
\hline Effigy & 1 & Iron arrow point & 2 \\
\hline Red-slipped bottle & P & Vermilion pigment & $P$ \\
\hline \multirow[t]{2}{*}{ Rattle bowl } & $P$ & Iron knife & 2 \\
\hline & & Pewter ring & 1 \\
\hline Natchitoches Engraved & 15 & Silver disk & 2 \\
\hline Simms Engraved & 18 & Brass disk & 2 \\
\hline Simms Engraved, var. Darco & 7 & Brass coils & $\mathbf{P}$ \\
\hline Taylor Engraved & 5 & Brass/copper braclet & $\mathrm{P}$ \\
\hline Patton Engraved & 2 & Sheet brass & $\mathrm{P}$ \\
\hline Hudson Engraved & 2 & Gun parts & 3 \\
\hline Keno Trailed & 1 & Axe & 1 \\
\hline Womack Engraved & $\mathrm{P}$ & Hoe & 1 \\
\hline \multirow[t]{2}{*}{ Hodges Engraved } & 1 & Strike-a-lite & 1 \\
\hline & & Brass tinkler & $\mathrm{P}$ \\
\hline Emory Punctated-Incised & 14 & Brass hawkbell & P \\
\hline Bullard Brushed & 7 & Gunflint & $\mathbf{P}$ \\
\hline Maydelle Incised & 3 & Lead balls & $\mathrm{P}$ \\
\hline LaRue Neck Banded & 4 & Glass beads & 2201 (41\% large), \\
\hline Clements Brushed & $\mathbf{P}$ & $1680-1800$ & \\
\hline Cass Appliqued & $\mathrm{P}$ & & \\
\hline Clay elbow pipe & 8 & & \\
\hline Fresno point & 8 & & \\
\hline Conch shell beads & 3 & & \\
\hline Stone pipe & 1 & & \\
\hline $\begin{array}{l}\text { Large stone blades } \\
\text { cf. Jowell/Anderson }\end{array}$ & 9 & & \\
\hline
\end{tabular}

P=present, but not quantified in Jones (1968)

The occurrence of Clements Brushed and Cass Appliqued vessels hints at some relationship/interaction with the Nasoni Caddo living in the Sulphur River basin, as best known at the Clements (41CS25) and Goode Hunt (41CS23) sites (Gonzalez et al. 2005). That Womack Engraved is present in the Kinsloe phase vessel assemblages suggests northern and western contact with Caddo groups living in the upper Sabine, Sulphur, and Red River basins, as these distinctive engraved vessel forms are found and likely made primarily in these areas. 
The Simms Engraved, var. Darco vessels replace the Darco Engraved type defined by Jones (1968). These globular and lip-notched bowls and carinated bowls with a discontinuous engraved motif have been previously recognized as Simms Engraved from earlier protohistoric and early historic Caddo collections like the Clements site (Gonzalez et al. 2005: Figures 4.10a and A.5.44-45), Susie Slade (Perttula 2006: Figure 188), the Hatchel site (41BW3), and Sam Kaufman (41RR16, see Skinner et al. 1969: Figure 2lc), but not categorized as a distinctive variety of Simms Engraved until now. At the Clements site, Simms Engraved, var. Darco likely dates from the late $17^{\text {th }}$ to the early $18^{\text {th }}$ century.

Bowls, jars, and bottles are the most common vessel forms, with only a few carinated bowls (Table 2). The utility wares (either plain or with wet paste decorations) are primarily jars, with some few bottles $(n=5)$ or bowls $(n=6)$ and one olla. All of the carinated bowls, $70 \%$ of the bottles, and $86 \%$ of the bowls are fine wares with engraved or trailed decorations or are specialized forms such as effigies $(n=1)$ or rattle bowls $(n=1)$.

Table 2. Kinsloe Phase Vessel Forms.

$$
\text { Vessel Forms (Types) No. }
$$

Carinated bowl, small shoulder (Simms Engraved, var. Darco) $\quad 7$

Bottle (Henderson Plain, Emory, Hodges, Taylor, Hudson) 20

Olla (Henderson Plain) 1

Bowl (Henderson, Emory, Natchitoches, Simms, effigy, rattle $\quad 43$

Patton, Hudson, Keno)

Jar (Henderson, Emory, Bullard, Maydelle, LaRue) 33

Jones (1968) notes that shell temper is present in about $10 \%$ of the vessels, but only among the following types: Natchitoches Engraved, Simms Engraved, var. Darco, Emory Punctated-Incised, and Henderson Plain. Otherwise, the tempers utilized are grog and bone (see Corbin, this volume).

There are also plain and engraved elbow pipes in Kinsloe phase sites, as well as marine conch shell beads, and a carved stone pipe (see Table 1). It is not unusual to find clay pigments in prehistoric and early historic Caddo burials-sometimes placed in mussel shell containers-and the Kinsloe phase sites are no exception. Jones (1968) documented green, gray, and red clay pigments from the local clay sources, and also notes the presence of a rich vermilion pigment that was obtained from the French in trade.

Not too surprisingly, the most common European trade good in the Kinsloe phase sites is glass beads (see Table 1). The proportion of large beads in the glass beads (41\%) suggests that the beads may primarily have been accumulated and placed with Kinsloe phase burials around the first quarter of the $18^{\text {th }}$ century (see Perttula 2005: Table 2). 
Other beads from Kinsloe phase dates described by Jones (1968) may indicate that the beads were accumulated throughout the $18^{\text {th }}$ century.

There is a wide variety of other European trade goods made from iron, pewter, brass, and silver. These are from discarded and broken muskets, lead balls, arrow points, knives, axes, and hoes made of iron, as well as ornaments (rings, tinklers, hawkbells, disks, and bracelets) made from brass and silver.

Aboriginal lithic tools in Kinsloe phase sites include triangular arrow points (cf. Fresno) and various large and/or bi-pointed chipped knives (Anderson and Jowell forms). There are gunflints in the assemblages, some of which may have been made or reworked by the Caddo.

\section{References Cited}

Gonzalez, B., R. Cast, T. K. Perttula, and B. Nelson

2005 A Rediscovering of Caddo Heritage: The W. T. Scott Collection at the American Museum of Natural History and Other Caddo Collections from Arkansas and Louisiana. Historic Preservation Program, Caddo Nation of Oklahoma, Binger, Oklahoma.

Jones, B. C.

1968 The Kinsloe Focus: A Study of Seven Historic Caddoan Sites in Northeast Texas. Master's thesis, Department of Anthropology, University of Oklahoma, Norman.

Perttula, T. K., with contributions by T. E. Emerson and R. E. Hughes

200541 HO64/41HO65, Late $17^{\text {th }}$ to Early $18^{\text {th }}$ Century Caddo Sites on San Pedro Creek in Houston County, Texas. Bulletin of the Texas Archeological Society 75:85-103.

Perttula, T. K.

2006 A Study of the Buddy Calvin Jones Collection from Northeast Texas Caddo Sites. Special Publication No. 6. Friends of Northeast Texas Archaeology, Austin and Pittsburg.

Skinner, S. A. R. K. Harris, and K. M. Anderson (editors)

1969 Archaeological Investigations at the Sam Kaufman Site, Red River Counly, Texas. Contributions in Anthropology No. 5. Southern Methodist University, Department of Anthropology, Dallas. 